\title{
SUSTAINABLE MARKETING - A NEW ERA IN THE RESPONSIBLE MARKETING DEVELOPMENT
}

\author{
Marek SERETNY*, Aleksandra SERETNY** \\ *Faculty of Management \\ Warsaw University of Technology, Warsaw, Poland \\ e-mail: m.seretny@wz.pw.edu.pl \\ **Investment Banking Industry in Hong Kong \\ e-mail: olaseretny@gmail.com
}

\begin{abstract}
The purpose of this paper is to draw to the attention of those involved in marketing - scientists, educators, researchers, marketers, and professionals dealing with the implementation of marketing processes the responsibility which rests upon them in the face of rapid social change worldwide through increasing global economic turbulence, a continuously widening gap between rich and poor societies as well as the galloping degradation of the natural environment. The paper is a critical analysis and literature review of marketing covering recent studies on marketing issues in relation to the concept of sustainability. Faced with increasing criticisms of a one-dimensional profit driven approach, the marketing concept requires rebranding to address issues of sustainability. Intense strategic discussion is required concerning the need to change attitudes that promote and implement modern marketing, starting from changes in the consumption model through the creation of commercial proposals, which will positively shape the future of both market exchange and social life. Moreover, it is postulated that marketers present to consumers an attitude of active and responsible management, as well as openness and honesty in market communication. The article introduces discussion on sustainable marketing and its fundamental importance in the development of marketing theory in Poland; taking into account current debates voiced in Poland - often based on imprecise interpretation of the marketing process. There exists therefore, a need for a thorough analysis and standardisation of understanding marketing theory and consequently the introduction of new concepts and new practices into the marketing process.
\end{abstract}

Keywords: sustainable marketing, responsible consumption, social responsibility.

\section{$1 \quad$ Introduction}

Economic development takes place with the active participation of marketing. Without exception, we are all participants in a changing market - every member of society will sooner or later become a consumer. Marketing undoubtedly acts as a stimulus to the development and improvement of living standards [12].

The individual concepts of marketing and sustainability are not new; in fact, both have evolved over several decades into drivers of strategy, competitiveness and innovation. It is only recently however, that the term 'sustainable marketing' was introduced into the business world and commenced a rapid re-branding of marketing as an industry. Since the beginning of the twentieth century and most intensively during the last sixty years marketing has evolved (see Fig. 1) - commencing as a product driven approach focused on intensively growing sales (Marketing 1.0) to a consumer centric focus (Marketing 2.0). Today we are witnessing the emergence of a new era, defined as Marketing 3.0, a value-driven era, where people no longer perceived as a target consumer market base on demographic factor but rather thoughtful and intelligent partners with emotions, feelings and specific spiritual values [72].

The current socio-economic landscape is shaped by two powerful forces: technology and globalization. Consumers expect organisations, operating both in market and society, to provide solutions that will make the globalised world a better place to live.

Despite contributing to economic growth through meeting the needs of growing number of new consumer groups, marketing has also attracted considerable criticism.

„Some authors are concerned that marketers might become the sightless psychopaths of market forces, gripped in the thrall of market capitalism with no overall vision of what they are trying to achieve" [12, p. 51]. 


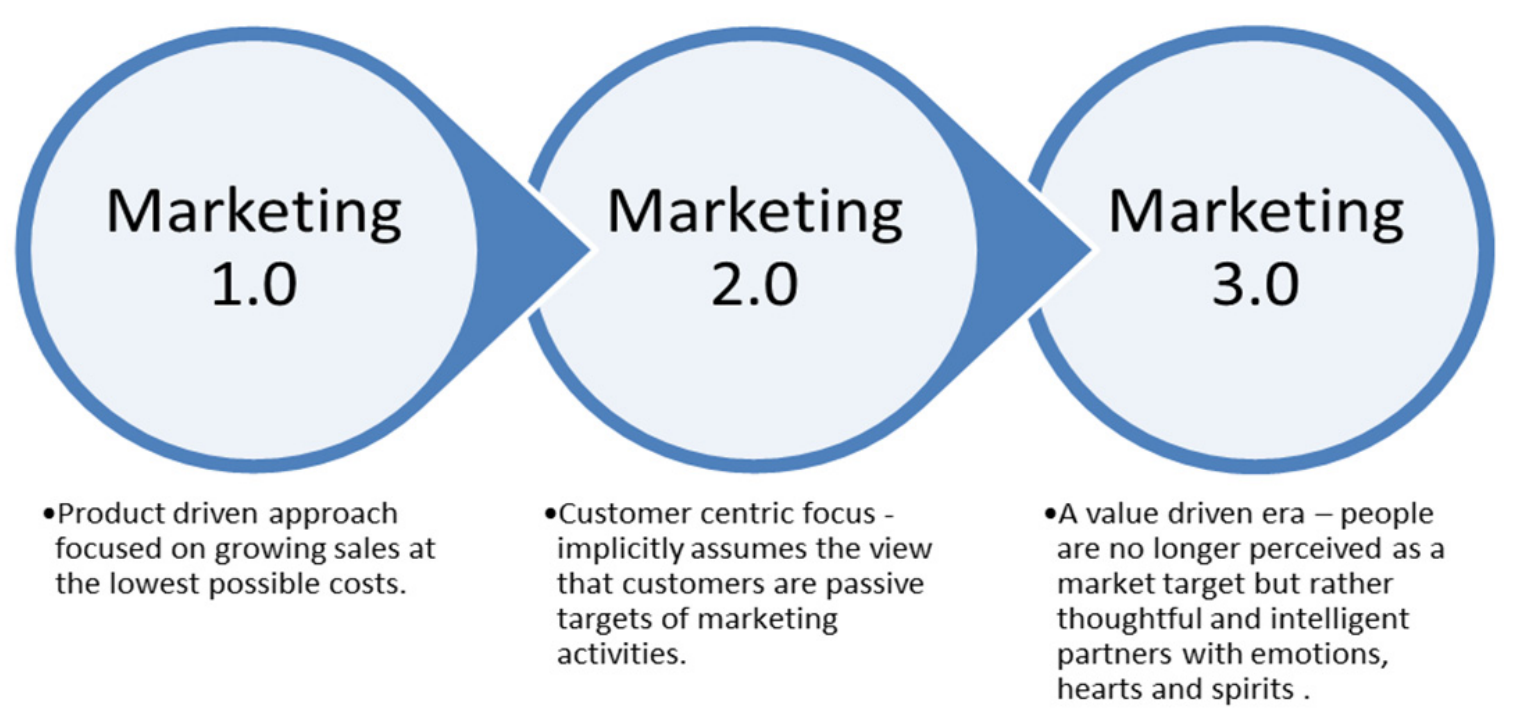

Figure 1. Marketing development (source: developed on the base of Kotler's concept of Marketing 3,0 [72])

Mounting concerns over the social and ethical accountability of corporations, particularly following financial scandals such as Enron and Worldcom, have seen increased commitments by corporations to areas surpassing direct fiduciary duties towards their shareholders. A fundamental aspect in this process has been the rise of social responsibility from its modest resurgence in the 1950's, into a complex and well publicised notion which has increasingly become central to present day corporate decision making [22]. Individual customers have themselves raised numerous reservations about the functioning of marketing. Marketing representatives have been accused of harming consumers primarily through the imposition of high prices on products and services resulting from the high costs of distribution, advertising, promotion, and excessive margins. Marketing is also accused of using devious means that fuel the consumer's belief that the resulting value is greater than actual, as exemplified in the controversial marketing of child products Marketing to children focuses on "pester power", where child products are not targeted at the adult but rather aim to exploit a child's ability to nag their parents into buying products they would normally not purchase ${ }^{1}$.

Consumers' great discontent and frequent frustrations are also caused by aggressive sales. Sellers are accused of carrying out commercial activities in an obtrusive

\footnotetext{
${ }^{1}$ http://www.mediaawarness.ca/english/parents/markeing/ marketers_target_kids.cfm)
}

way, persuading customers to purchase products or services they did not intend to purchase. The most troublesome problem for the individual consumer is the implementation of the so-called planned obsolescence strategy [71, pp. 608-613].

We should also note that the criticism of marketing is formulated not only in relation to activities aimed at individual consumers. Marketing is accused of harming society as a whole. In the format that it is presented in developed countries, marketing is blamed for creating false needs, fuelling greed, and even inciting communities to over-consumption and materialism. The World Health Organization for many years has been paying attention to the problem of obesity in developed countries [59]. Marketing also tends to promote excessive interest in having - people are judged by what they have rather than by who they are. Finally, marketing is also responsible for environmental degradation as well as trivialization and destruction of cultural and social environment [71, op. cit. pp. 613-618].

\section{Social responsibility}

Modern marketing and management places an important significance on building relations with the customer based on values connected with the public interest, interpersonal relationships and trust. 
Contemporary marketing literature ([23], [53], [58], [60], [72] and [108]) discusses moral and socially responsible behavior as an integral part of the marketing process.

Despite observing an increase in understanding of the importance of social responsibility in business approach, its place in the corporate model is debatable as stated by one of the leading economists of the twentieth century "the social responsibility of business is to increase its profits" [44]. Traditional economic reasoning suggests that the wealth maximisation of shareholders, as the owners of firms, should only be considered by managers. In fact, Friedman goes as far as to consider actions diverting from such priorities as the levy of 'illegal tax'. Friedman argues that only human beings have a moral responsibility for their actions and that corporations are not human beings but solely legal entities. He further argues that social issues and problems should be the responsibility of the state and not that of corporate managers.

Milton Friedman's vigorous opposition towards the concept of social accountability of corporations has over the years become a cornerstone questioning the relevance of social responsibility in the business world. Mintzberg [84] terms social responsibility 'the most naive of concepts' though one, without which, modern day society cannot sustain itself.

Corporate Social Responsibility (CSR) is deemed 'a concept whereby companies integrate social and environmental concerns in their business operations and in their interaction with their stakeholders on a voluntary basis' [38]. Another definition of CSR emphasises "actions that appear to further some social good, beyond the interest of the firm and what is required by law" [82]. Heightened interest and activity in CSR has not subdued the inherent conflict between augmenting profits or adhering to the triple bottom line and, inter alia, multiple stakeholders. Crane and Matten [24] state that the apparent practice of CSR by firms is often based on self-interest and research by Moon [85] confirms that the increasing institutionalisation of CSR is related to government intervention rather than voluntary support for the concept and its long-term business case.

Despite this, studies conclude that employees and consumers respond positively towards undertaken CSR efforts implemented by firms ([15], [64] cited [63]). Furthermore, research reveals that shareholder interest in environmental and social issues has been significant- ly increasing [4] and that, shareholder wealth, may in fact be connected to the maximizing of stakeholder surpluses. As such it is not surprising to observe a rise in ethical investments of more than $324 \%$ from US\$ 639 billion in 1995 to US\$ 2.7 trillion in 2007 in the United States alone [105]. The emergence of numerous ethical and sustainable indices, such as the FSTE4Good Indices, Domini 400 Social Indices, ASPI Eurozone ${ }^{\circledR}$ (Advanced Sustainable Performance Indices) and the Dow Jones Sustainability Indices portray further evidence of the expanding appetite for ethically sound investments.

Peter Ducker in the 1960s and 70s insisted that the companies and organizations applying marketing, profit or non-profit oriented, should become public bodies. None of them exist solely for themselves; they serve a social purpose and satisfy certain social needs, both of wider communities and or individuals. Performance of certain tasks, production of economic goods and providing services involve influencing individuals and their natural environment. These behaviors must have an impact on the social environment, because it is not only a source of jobs and income, also in the form of local taxes, but in many cases it becomes a source of waste and pollution. Moreover, in our pluralistic society with its various organizations, a company should feel responsible for the quantitative effects which influence lives - economic goods and services; for the quality of life in its physical, human and social aspects; and for the environment of a person in contemporary society [33, p. 35].

Some studies suggest that some forms of social responsible behavior may in fact improve future cash flows. Product differentiation may occur as a consequence of CSR, for example through the introduction of new environmentally friendly or Fair Trade lines [82]. Several studies concur that ethical practices can aid avoidance of hefty governmental fines ([14], [101] and [42]). Consequently Godfrey [50] finds that socially responsible practices can reduce risk exposure of an organisation.

Despite a lack of consensus as to the definition and implementation of socially responsible behaviors by a firm Burke \& Logsdon [17] argue that CSR does create value for a firm. Their study focuses on analyzing CSR-programs as creators of strategic benefits of a company. The authors conclude that value can only be generated when CSR is imbedded in the strategic direction of the organisation. 


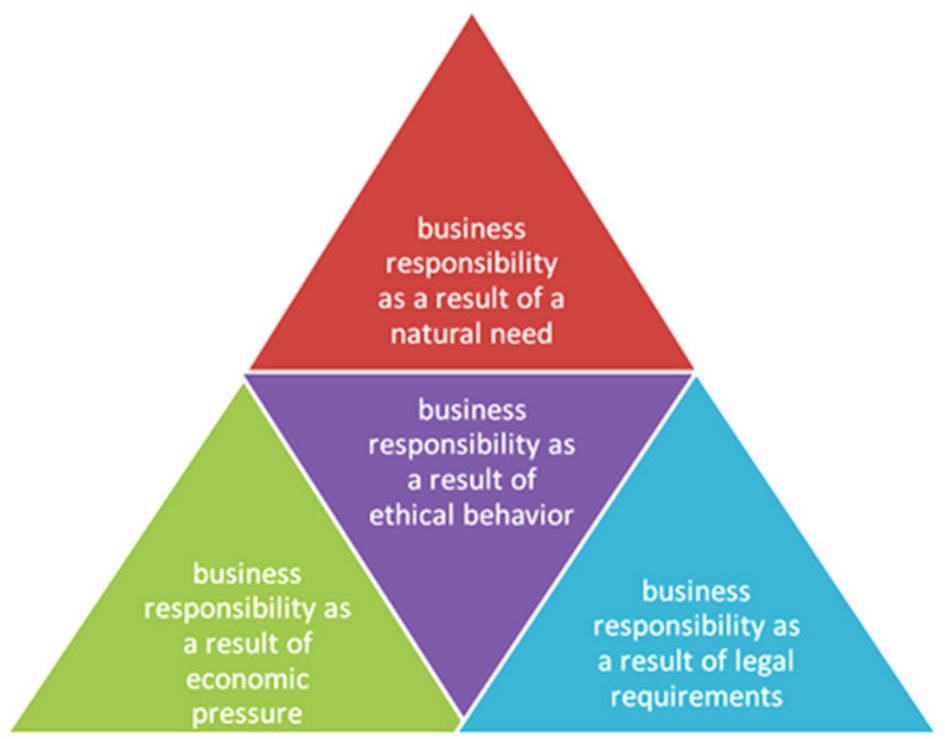

Figure 2. Pyramid of socially responsible practice (source: self-study)

It is only then that no trade-off between social and economic interests but rather CSR activities may serve both financial and social interests.

The notion that organisation use social measures such as; ISO ratings, Fair Trade and Sustainability certifications to advance their own political and economic agendas is explored by David \& Rindova [28].

The authors consider such measures as 'drawing on valuation tools of quantification and simplification to compare firms along a common, often non-financial, metric' [28]. The study finds that social measures of firms are strongly related to perception rather what they are or are not. Furthermore, the aforementioned measures are considered to be 'representations and distortions of reality that enable certain actions, while constraining others'.

As depicted, the field of social responsibility evokes debate and its complexity is unquestionable, however with the infamous economic question of limited resources sustaining unlimited wants is steadily demonstrable through degrading environmental and economic factors thus $t$ strategic aspect of conducting business today involves the need for companies to shoulder responsibility for the environment in which they operate. The movement for environmental protection and consumer rights, using all possible (often extreme) means of communication and pressure is becoming uncompromising and the companies and organizations are increasingly open to its demands and proposals. A new society arises before our eyes, integrating itself thanks to globalization, development of new technologies and creation of new communication opportunities, around economic and social objectives. A global corporation operating locally becomes a symbol of our times, a person in charge - a symbol of managerial capitalism [96, p. 11].

All managers, whether they like it or not, are responsible for the impact the organization they guide exerts upon the outside world. Therefore a very important task of the managers is to notice and predict the possible influence of their company on society. They should rethink this in a cool and realistic manner, for it is not about finding answers to the question: Are we doing well what we are doing? but: Is whatever we are doing that for which society and the customer pay us?, and Is it consistent with the customers' needs and the needs of their society? [33, p. 88]. Managers should apply the criteria for assessing whether they practice socially responsible business (see Fig. 2). The level of social responsibility has four dimensions; economic, legal, ethical, and ultimately in the attitude known as "unconstrained activity" (often also assisted as a philanthropy) resulting from the need to create and do good.

The success of the company and continuing successful catering for the needs of clients and other participants in the marketing process are associated with maintaining high standards of conduct. 


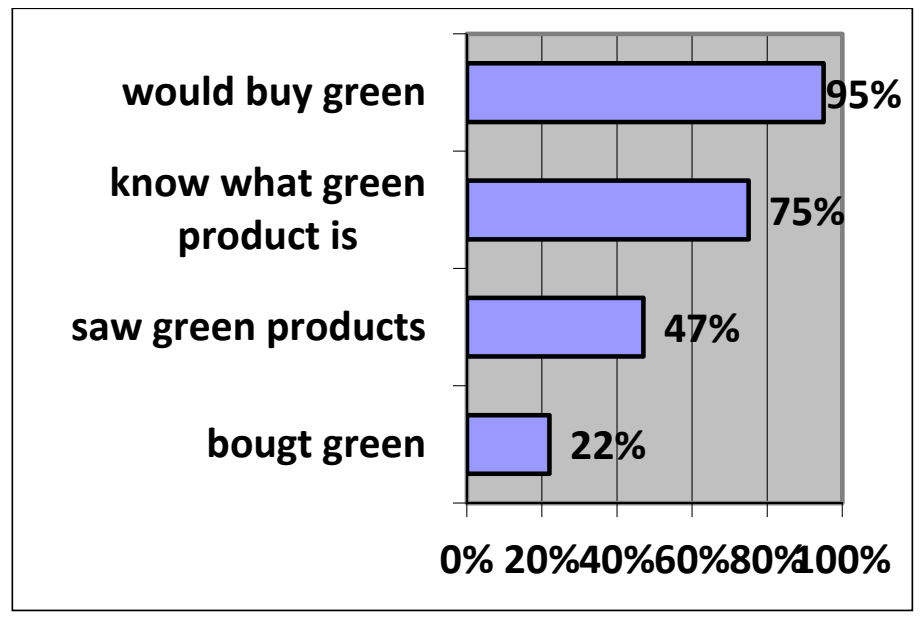

Figure 3. Sustainability shopping trends (source: [93])

\section{3}

\author{
Sustainable Marketing - a new trend \\ or necessity
}

\subsection{Global trends}

The starting point for the preparation and implementation of effective marketing solutions is understanding the market, as well as the needs of the people, businesses and organizations that form it. Dynamic technological progress constantly brings change among consumers, creates new market solutions, and thus develops the concept of marketing.

The development of computer technology together with globalisation has created a new wave of communication between individuals, and between spontaneously formed groups. This allows for unlimited expression of one's thoughts and ideas, while building global relationships. One of the significant effects of the dominance of information technology is the explosion of social media, which due to their wide availability, low price, and above all, freedom of speech and impartiality now has become the more important approach to marketing communication. While considering the development of information technology, we should emphasize their importance in the development of unrestricted cooperation, providing the ability to simultaneously work on the projects regardless of the distance separating them, through the formation of open source capabilities demonstrated by solutions such as Linux software and the Wikipedia.

A twenty-first century phenomenon of open cooperation is a free forum for exchange of experiences TED Technology, Entertainment, Design conferences, organized by the U.S. non-profit Sapling Foundation, and outside the United States - TEDx, $\mathrm{x}=$ independently organized TED event - which create an innovative look at the economic, social or cultural reality. Conferences are held in almost every part of the world, and their common mission is to popularize "ideas worth spreading" that can change the world for the better. Today, TED has become a global community, communicating mainly in English but also in more than 50 other languages. It brings together "people from every discipline and culture who seek a deeper understanding of the world" (www.ted.com).

The growing cooperation of consumers using social media and mobile technologies has a great influence on marketing. Marketers are no longer able to fully control messages that create the image of their market offer. Companies more than ever before are forced to cooperate with consumers who are growing in strength. Prospective consumers engage in creating new product and service solutions that will meet their needs, discuss and evaluate the prices, and take part in the assessment and creation of advertising proposals and more increasingly influence strategic change for social good.

Consumers are becoming more active participants in the creation of the sustainable economy, demanding greater transparency over the origin and contents of the goods they consume, and increasingly aware of the broad sustainability challenge facing the world [93]. For example, some $95 \%$ of American consumers say they are willing to "buy green" (see Fig. 3) and $44 \%$ say their "green" buying habits have not changed, and more than one-third report that they are more likely to buy sustainable products. 
The market for products is, in fact, predicted to grow significantly: a recent report for the German government suggests that Germany will earn more money from green products than from car production by 2020 [93, op. cit. p. 14].

\subsection{Sustainable Marketing}

The underlying notion of marketing is the creation of value by understanding consumer needs, often translated into understanding a given demographic so as to maximise sales and profit. Any drivers towards sustainability could therefore surface if the bottom line would increase accordingly.

Increasingly in recent years companies have been apportioned as the cause of social, environmental and economic problems, leading to crises of a magnitude that is unprecedented in the history of capitalism such as the global financial crisis of 2008 , the current East Africa food crisis and the catastrophic oil spills of the past decade. A consequence of decades of business philosophy which sees market activities in a narrow way, primarily through the prism of financial results and conducting business at the expense of society and not for the benefit of society. Moreover, frequent failures to keep promises resulting from previously adopted principles of corporate social responsibility have shaken public confidence in the business and its leaders [91].

Concerns over the fragile state of the globe's natural resources, the damaging consumer footprint on our environment as well as the unbalanced state of world economies have added pressure to sustaining a bottom line vastly dependent on increasing monetary profit. The present situation clearly shows that companies and organizations, and especially their leaders have to rebuild relationships and trust among all participants in the economic scene by proposing a new model of doing business. Thus, the need has arisen to redefine profit with the inclusions of environmental and social revenue and the marketing mix to include the new concept of 'profit' as a foundation.

The underlying philosophy of "Sustainable Marketing", which Kotler calls Marketing 3.0, seems to be a business model that could meet the people's needs, increase the efficiency of the development of global society, create new jobs and raise the level and quality of life for today and tomorrow.
In the first instance, marketers are responsible for promoting sustainable consumption, which was placed as a key challenge for the global community at the Earth Summit in Rio de Janeiro in 1992. Based on three pillars - economic, social and environmental - responsible consumption involves the use of the goods in a more efficient and responsible manner, suggesting an equitable distribution of resources between rich and poor societies [8].

Scientists and educators face the challenge to change the present paradigm, which shows the marketing and responsibility (or, in the broader sense, sustainability) as opposites [60].

Discussion on the essence of marketing and formulation of robust paradigms - especially on the Polish market - which are a source of erroneous assessments of the process is due to an unfortunate identification of marketing with "aggressive sales", advertising, or PR. This interpretation may result from the inconsistent use of the word "marketing" in the Polish translation of the book by Philip Kotler. In some situations, it means the ideal model of market exchange and cooperation, in others - sales and promotion activities. Kotler's intention was obviously to use this term in order to define this ideal model, and not other cases of applying advertising techniques or social influence, devoid of features necessary in marketing: reciprocity, exchange and understanding needs. This interpretation is obvious after a careful reading of his book, as well as other publications on marketing. Not without reason, Kotler's marketing lecture starts from the presentation and critique of sales orientation [65].

Interesting example of the paradigm functioning in Poland is the opinion voiced by Gasparski [47] who, quoting the synthesis of the overview of various aspects of economic life, conducted by the Sociology Committee of the Polish Academy of Science (PAN) from the ethical perspective, talks about the unethical, aggressive and irresponsible marketing, and its impact on shaping people's materialistic personality. The author of this synthesis, Aniela Dylus, writes about the influence of marketing on the formation of human mercantile personality: "[...] a general reflection about the risks associated with marketing, as an essential element of the market, is indirectly related to our situation. 


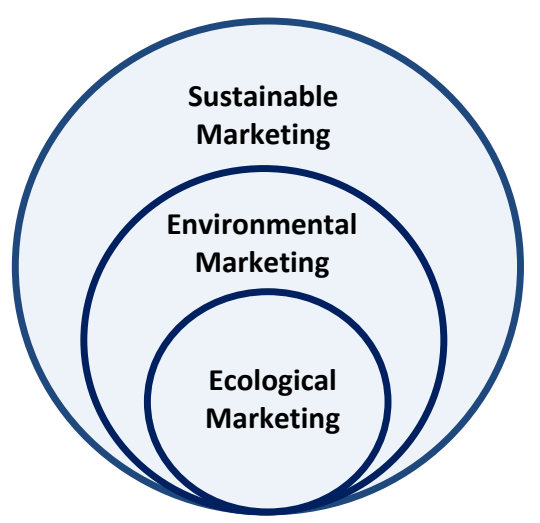

Figure 4. Sustainable marketing development (source: self-study)

Besides, the author of one such analysis, referring to the typology of characters by E. Fromm and R. Funk, points straight out: the syndrome of the marketing character seems [...] very characteristic and topical in the Polish economy in the era of transformation.

Mercantile character includes such features as opportunism, flexibility, mobility, separateness by individualization, coldness due to loss of emotions, selfishness by commercialization. For they allow you to sell well on the personality market, and thus determine your success in life" [47].

Such differences in perception of marketing in Poland create an optional platform for re-definition and education of the newer marketing concept and make clear that the relationship between marketing and sustainability is becoming stronger $[60$, p. 123$]$ and more necessary.

The Marketing concept conceived as a broadly defined philosophy of action, a way of thinking and doing business, and as a management process that allows individuals and organizations to get what they need and desire to achieve through creating, offering and exchanging products and services of value [71, p. 29] fits in the definition of sustainability.

In Poland, the concept of sustainability is commonly used as zrównoważony (stable, balanced) in the areas of development or environment protection (sustainable development, sustainable environmental economy, etc.). This understanding (perhaps it is a matter of translation) significantly limits the concept. Mean- while, it should be defined much more broadly, as ,sustainability is a collective term for everything to do with responsibility for the world in which we live. It is an economic, social and environmental issue. It is about consuming differently and consuming efficiently. It also means sharing between the rich and the poor and protecting the global environment while not jeopardizing the needs of future generations" [60, p. 125].

Sustainable marketing should therefore be seen as marketing, which is a part, but especially a supporting element, of sustainable economic development. Within the framework of sustainable development, marketing has undergone a three-step evolution [58] (see Fig. 4). The first phase dates back to the 1970s: ecological marketing, focusing on ecological problems, such as air and water pollution, depletion of natural resources, and environmental impact of fertilizers and pesticides used in agriculture. The second stage is the 1980s: environmental marketing, focused on developing modern, environmentally friendly "clean" technologies. In the center of marketing activities was "green customer segment", seeing the responsible action as a competitive advantage. The third stage is the current era of sustainable marketing, which aims at responsible economic and social development.

Sustainable marketing focuses on meeting the needs of today's consumer but moreover including the next generations of consumers and the possibility of meeting their needs. Sustainable marketing is also seen as a philosophy with a goal to bring together participants in the market, social activists and organizations whose 


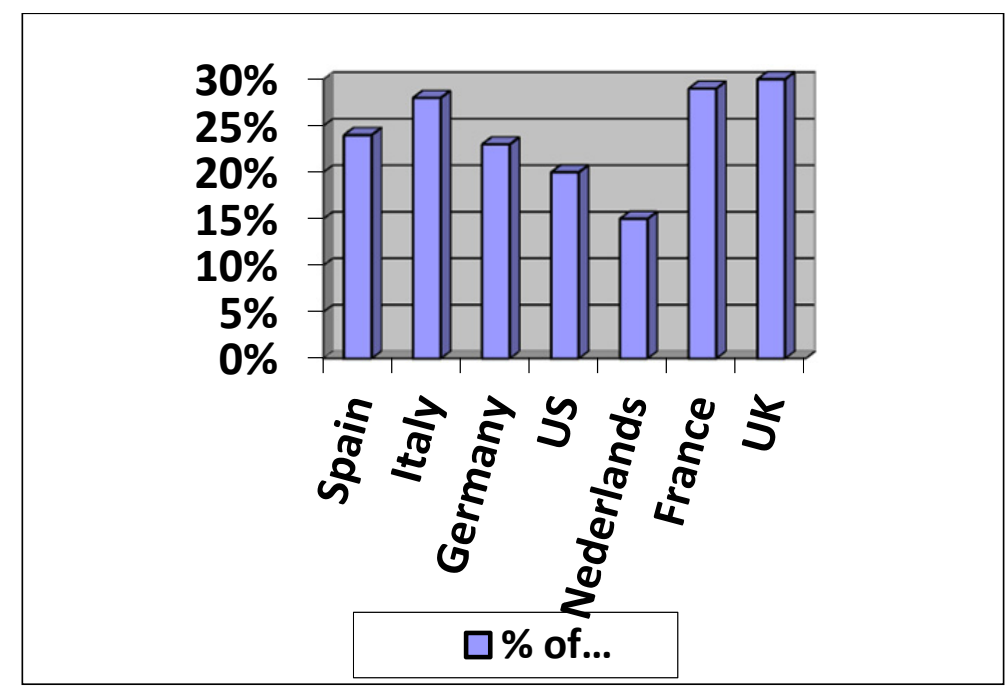

Figure 5. $\%$ of population that purchase sustainable brands (source [113])

interests have not coincided so far, in order to create a common worldview through the prism of the responsibility for protecting and preserving the environment, social responsibility and wise management of global financial resources.

The research conducted on European most advanced markets in terms of implementation of sustainability, as well as in US, shows that responsible customers require action from marketers. There is a growing pressure on business and marketing leaders to be concerned about society and at the same time about their own families, lifestyles and professional legacies and act to insure that this is no passing fad [114].

The marketing professionals as influencers, communicators and shapers of culture, have abilities to ensure that they make a significant difference both to their customers and the environment. In practice they have been looking at the products and/or services, assessing how they impact the environment and then taking actions to minimize those negative impacts.

Customers are looking for brands they feel have commitments to environmental and social issues and "they are voting with their wallets" (see Fig. 5).

Kevin Roberts CEO Worldwide of Saatchi \& Saatchi stated: "Every client sees sustainability as a priority issue and every employee and customer wants to be part of a bigger idea. No brand will be truly loved by anyone it touches unless it shares an inspired, sustainable benefit" [114, op. cit. p. 10].

The most effective campaigns to encourage ethical consumption are those that take place at a collective level, such as the creation of Fair Trade offers (see Fig. 6), rather than those that target individual behavior.
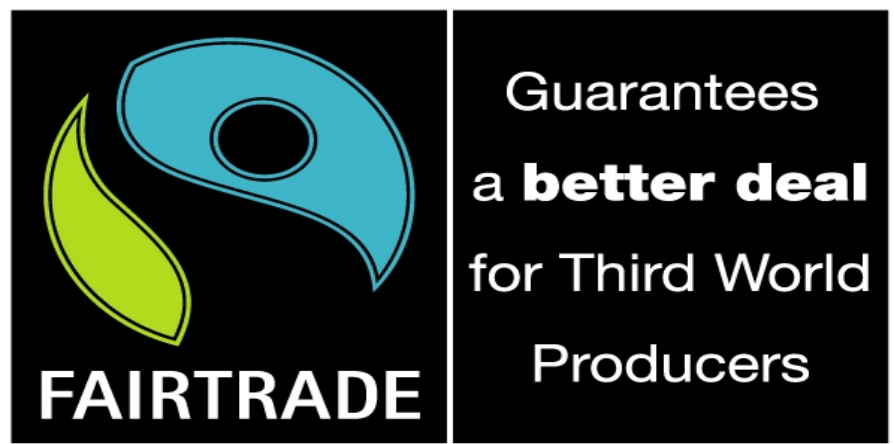

Figure 6. International logo of Fair Trade influencing ethical consumption. (source:http://thesituationist.wordpress.com/2007/08/16/the-situation-of-ethical-consumption/) 


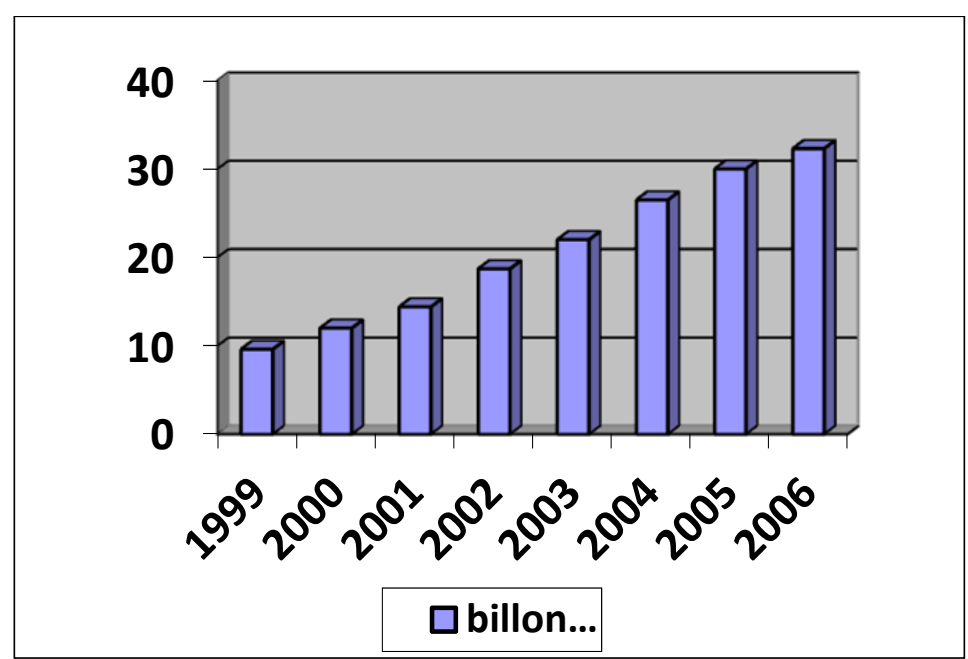

Figure 7. Customer spending on ethical consumption in UK (source: [113])

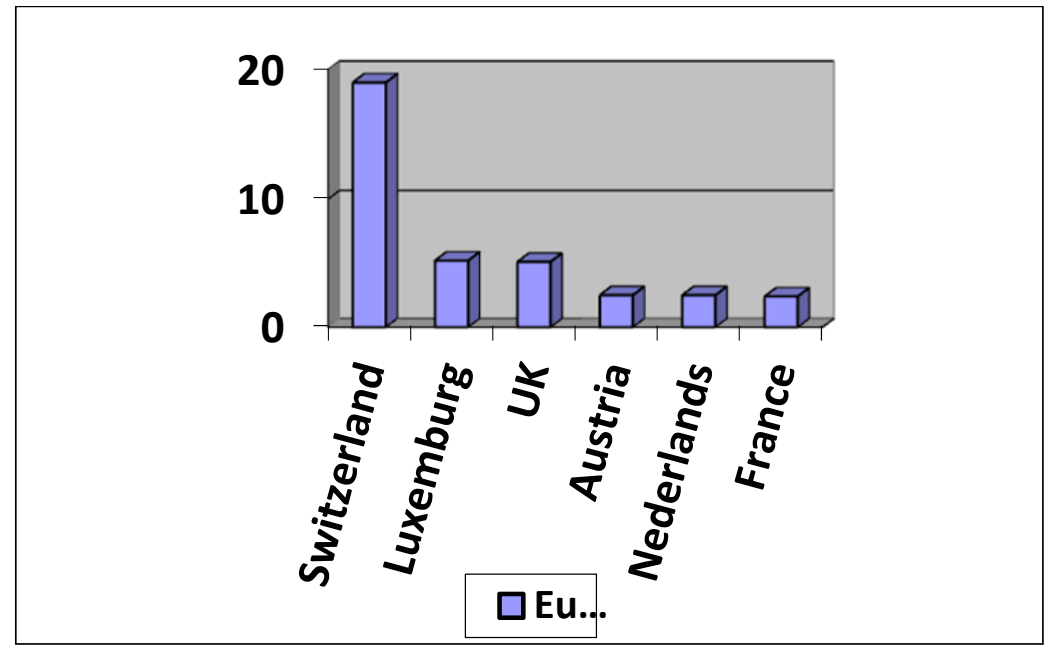

Figure 8. Average consumption of Fair Trade Products per capita (source: [113])

According to the Ethical Consumption and Fair Trade Fundation Reports [113, op. cit. p. 10] in Europe, favorable attitudes towards sustainable purchasing are becoming widespread (see Fig. 5). Value of ethical spending in the UK for example grown $9 \%$ in 12 months (2006-2006) to 32,3 billion GBP (see Fig. 7), while sales of Fair Trade products in the UK grew by a staggering $81 \%$ from 2006 to 2007.

Fair Trade is also a barometer of consumer attitudes to ethical consumption and sustainability. Fig. 8 demonstrates that average per capita consumption of Fair Trade products in Europe is becoming economically significant.

\section{Summary}

Today's economy is experiencing serious economic and social problems affecting all citizens of the world, both rich and poor. The earth seems to become insufficient to meet the standards of living that the developed societies expect.

Marketing is seen as the cause of many such problems. It contributed to the emergence of the behaviors that should be changed. With its indisputable impact on market development, marketing has a strong influence on degradation, but it can also build positive behaviors of consumers, enterprises, organizations, and entire societies. Understood as a philosophy of action, a way of thinking and doing business, sustainable marketing promotes credibility and responsi- 
bility, leading to better consumption, better relationships, and more responsible business, thus influencing the creation of a better world.

Sustainable marketing is not just about producing better and cheaper, and refrain from cutting down trees. This is a genuine practical value of doing business, which influences efficiency, inspires creativity, promotes and preserves cooperation. Thanks to balancing the needs of people, global environment and economic development in the long run, sustainable marketing provides businesses and organizations with faith and strength to create "more" while using less funds and resources.

On an operational level, sustainable marketing aims to influence customer behavior and utilise consumer social evolution in order to create positive social change and thus to achieve a new long-term profit. It is also meant to influence what the customer receives create brands that are part of the commercial and social future. Finally, it is supposed to provide goods and services, through managing in a responsible manner, being open to fair cooperation in marketing communication.

\section{$5 \quad$ References}

[1] Adams R., Carruthers J., Hamil S. - Changing Corporate Values. Kogan Page, 1991.

[2] Al-Khatib J.A., D'Auria S.A., Rawwas M.Y.A. Ethical Segmentation of Consumers in Developing Countries: A Comparative Analysis [in] International Marketing Review, Vol. 22, No 2, 2005, pp. 225-246.

[3] Allen F., Carletti E., Marquez R. - Stakeholder Capitalism, Corporate Governance and Firm Value. EUI Working Paper ECO, 2008.

[4] Amble B. - Investor Interest in CSR is on the Rise. 2003, http://www.management-issues.com/2006 /8/24/research/investor-interest-in-csr-is-on-therise.asp (accessed on February 2009).

[5] Ashton D., Tippet M. - Systematic Risk and Empirical Research [in] Journal of Business Finance and Accounting, No. 25, 1998, pp. 13251362.

[6] Aupperle K.E., Carroll A.B., Hatfield J.D. An Empirical Examination of the Relationship Between Corporate Social Responsibility and Profitability [in] The Academy of Management Journal, Vol. 28, No. 2, 1985, pp. 446-463.
[7] Balabanis G., Phillips H.C., Lyall J. - Corporate Social Responsibility and Economic Performance in the Top British Companies: Are They Linked? [in] European Business Review, Vol. 98, No. 1, 1998, pp. 24-44.

[8] Bartels G.C., Nelissen W. (eds.) - Marketing for Sustainability: Towards Transactional PolicyMaking. Amsterdam, NLD: IOS Press, 2002.

[9] Becchetti L., Ciciretti R., Hasan I. - Corporate Social Responsbility and Shareholder's Value: An Event Study Analysis. Federal Reserve Bank of Atlanta Working Paper, 2007.

[10] Bird R., Hall A.D. Momente F., Reggiani F. - What Corporate Social Responsibility Activities are Valued by the Market? [in] Journal of Business Ethics, No. 76, 2007, pp. 189-206.

[11] Boega F., Campos A.S., Camino D. - Did the Creation of ISE Created Value to Companies? XXXII Encontro da ANPAD, 2008.

[12] Borland H., Paliwoda S. - Marketing Responsibility in an Era of Economic and Climactic Challenge [in] Marketing Intelligence \& Planning, Vol. 29, No. 1, 2011, pp. 49-62.

[13] Bourassa M. A., Cunningham P. H., Handelman J.M. - How Philip Kotler Has Helped to Shape the Field of Marketing [in] European Business Review, Vol. 19, No. 2, 2007, pp. 174-192.

[14] Bragdon Jr. J.H., Marlin J.A.T. - Is Pollution Profitable? [in] Risk Management, Vol. 19, No. 2, 1972, pp. 9-18.

[15] Brammer S., Millington A., Rayton B. - The Contribution of Corporate Social Responsibility to Organizational Commitment [in] The International Journal of Human Resource Management, Vol. 18, No. 10, 2007, pp. 1701-1719.

[16] Burchell J., Cook J. - It's Good to Talk? Examining Attitudes Towards Corporate Social Responsibility Dialogue and Engagement Processes [in] Business Ethics: A European Review, Vol. 15, No. 2, 2006, pp. 154-170.

[17] Burke L., Logsdon J.M. - How Corporate Social Responsibility Pays Off? [in] Long Range Planning, Vol. 29, No. 4, 1996, pp. 495-502.

[18] Campbell C.J., Cowan A.R., Salotti V. - MultiCountry Event Studies Methods (2010), http://papers.ssrn.com/sol3/papers.cfm?abstract_id $=1359798($ accessed on September 2012). 
[19] Carr S.C., Rugimbana R.O. - Marketing and Development out of Poverty: Introduction to the Special Issue [in] International Journal of Nonprofit and Voluntary Sector Marketing, Vol. 14, 2009, pp. 95-100.

[20] Chatterji A.K., Levine D.I., Toffel M.W. - How Well Do Social Ratings Actually Measure Corporate Social Responsibility? Working Paper of the Corporate Social Responsibility Initiative, 2007.

[21] Cherniss C., Goleman D. - The Emotionally Intelligent Workplace. Hoboken, NJ: John Wiley \& Sons, Inc., 2001.

[22] Cochran P.L. - The Evolution of Corporate Social Responsibility. Business Horizons, No. 50, 2007, pp. 449-454.

[23] Crane A., Desmond J. - Societal Marketing and Morality [in] Europeana Journal of Marketing, Vol. 36, No 5/6, 2002, pp. 548-569.

[24] Crane A., Matten D. - Business Ethics (2nd ed.). Oxford University Press, 2007.

[25] CSR Quotes. (n.d.). Retrieved 2009, http://www.gaia.com/quotes/topics/corporate+socia $1+$ responsibility.

[26] Curran M.M., Moran D. - Impact of the FTSE4Good Index on Firm Price: An Event Study [in] Journal of Environmental Management, No. 82, 2007, pp. 529-537.

[27] Czajkiewicz Z.J., Grudzewski W.M., Hejduk I.K. Leadership and New Science. Economics and Organization of Enterprise, Vol. 2, No. 2, Warsaw, 2008.

[28] David C., Rindova V.P. - Would You Like Fries With That? Producing and Consuming Social Measures of Firm Value [in] Proceedings of the Sixty-Sixth Annual Meeting of the Academy of Management (ed. G.T. Solomon), 2008.

[29] Dołhasz M., Fudaliński J., Kosała M., Smutek H. Podstawy zarzqdzania. Koncepcje - strategie - zastosowania. PWN, Warszawa 2009.

[30] Dow Jones Indexes, STOXX, SAM. (2008, September). Guide to the Dow Jones Sustainability World Indexes, from Dow Jones Sustainability Index: http://www.sustainability-index.com/ djsi_pdf /publications/Guidebooks/DJSI_World_Guidebook 10_1.pdf (accessed on November 2008).

[31] Du S., Bhattacharya C.B., Sen S. - Reaping Relational Rewards from Corporate Social Responsibility: The Role of Competitive Positioning [in] International Journal of Research in Marketing, Vol. 24, No.3, 2007, pp. 224-241.
[32] Durcker P.F. - Managing for Results. HarperCollins Publishers, New York, 1986.

[33] Durcker P.F. - Myśli przewodnie Duckera. MT Busines, Warszawa, 2001 (in Polish).

[34] Durcker P.F. - Praktyka zarzadzania. MT Busines, Warszawa 2008 (in Polish).

[35] Durcker Peter.F.: Zawód Menadżer. MT Busines, Warszawa, 2004 (in Polish).

[36] Durcker P.F: New Trends in Management Become Grounded in Basic Principles [in] Executive Excellence, Vol. 20, No 8, pp. 8-10, 2003.

[37] Elton E.J., Gruber M.J., Brown S.J., Goetzmann W.N. - Modern Portfolio Theory and Investment Analysis. John Wiley \& Sons, Inc., 2007.

[38] European Commission: Promoting a European Framework for Corporate Social Responsibility Green Paper. European Commission, 2000.

[39] Fama E.F. - Efficient Capital Markets: A Review of Theory and Empirical Work [in] Journal of Finance, Vol. 25, 1970, pp. 383-417.

[40] Fama E.F. - Efficient Markets: II [in] The Journal of Finance, Vol. 46, No. 5 , 1991, pp. 1575-1617.

[41] Finch N. - The Emergence of CSR and Sustainability Indices (2005),

http://papers.ssrn.com/sol3/papers.cfm?abstract_id $=902201$ (accessed on November 2008).

[42] Freedman M., Stagliano A.J. - Differences in Social-Cost Disclosures: A Market Test of Investor Relations [in] Auditing and Accountability Journal, Vol. 4, No. 1, 1991, pp. 68-83.

[43] Freeman E.R., Evan W.M. - Corporate Governance: A Stakeholder Interpretation [in] Journal of Behavioral Economics, Vol. 19, No. 4, 1990, pp. 337-359.

[44] Friedman M. - The Social Responsibility of Business is to Increase Its Profits [in] New York Times Magazine, 1970, September 13, p. 33.

[45] FTSE - FTSE4Good Index Series Factsheet (2008), http://www.ftse.com/Indices/FTSE4Good_Index _Series/Downloads/FTSE4Good_Factsheet.pdf (accessed on November 2008).

[46] Gaile-Sarkane E. - Diversity of Marketing - Trends and Development [in] Economics and Management, Riga University of Technology, Faculty of Economics \& Management, Vol. 15, 2010.

[47] Gasparski W. - Etyczność marketingu - marketingiem etyczności. Business Ethic Center IFiS PAN \& WSPiZ im L. Koźmińskiego, Warszawa, 2004. 
[48] Geczy C., Stambaugh R.F., Levin D. - Investing in Socially Responsible Mutual Funds (2005), http://papers.ssrn.com/sol3/papers.cfm?abstract_id $=416380$ (accessed on September 2012).

[49] Godfrey P.C. - The Relationship Between Corporate Philanthropy and Shareholder Wealth: A Risk Management Perspective [in] Academy of Manage-ment Review, No. 30, 2004, pp. 777798.

[50] Godfrey P.C., Merril C.B., Hansen J.M. - The Relationship Between Corporate Social Responsibility and Shareholder Value: An Empirical Test of The Risk Management Hypothesis [in] Strategic Management Journal, 2008. Vol. 30 No 4, pp. 425446.

[51] Goldberg C. - Too Much of Good Thing. The Boston Globe, February, 2006

[52] Grudzewski W.M., Hejduk I., Sankowska A. Trust Management - The New Way in The Information Society, Economics and Organization of Enterprise, Vol. 2, No. 2, Warsaw, 2008.

[53] Grudzewski W.M., Hejduk I. - Trust in Corporate Strategy Development. Economics and Business Administration Journal, Warsaw School of Economics, Warsaw, 2009,

[54] Grudzewski W.M., Hejduk I.: Trust Management as a base of New Economy Management Practices [in] Economics and Organization of Enterprise, Vol. 4, No. 2, Warsaw, 2009.

[55] Hamilton J.T. - Pollution as News: Media and Stock Market Reactions to the Toxics Release Inventory Data [in] Journal of Environmental Economics and Management, 28, pp. 98-113.

[56] Henderson D. - Misguided Virtue: False Notions of CSR. IEA Publications, 2001.

[57] How Marketers Build Sustainable Success? Business in the Community, Registered details 137 Shepherdess Walk, London N1 7RQ, London, February 2010.

[58] Hunt Shelby D. - Sustainable Marketing, Equity, and Economic Growth: A Resource-Advantage, Economic Freedom Approach [in] Journal of the Academy Marketing Science, Vol. 9, No. 39, 2011, pp. 7-20.

[59] James P.T., Leach R., Kalamara E., Shayeghi M. The Worldwide Obesity Epidemic, OBESITY RESEARCH, Vol. 9, Suppl. 4, November 2001.

[60] Jones P., Clarke-Hill C., Comfort D., Hillier D. Marketing and Sustainability [in] Marketing Intelligence \& Planning, Vol. 26, No. 2, 2008, pp. 123130.
[61] Jones E.A. - Company Investment Decisions and the Market Value of the Firm. Heriot-Watt University PhD, 2002.

[62] Kadirov D, Varey R. J. - Future Marketing: Dialectics of Post-Industrial Development [in] Journal of Customer Behaviour, 2010, Vol. 9, No. 4, pp. 357-377.

[63] Karlsson J., Chakarova Y. - Does Corporate Social Responsibility Pay Off? (2007),

http://hdl.handle.net/2077/9911 (accessed on November 2008).

[64] Klein D. - Engaging Employees through Social Responsibility. Leader to Leader, No. 46, 2007, pp. 56-58.

[65] Klincewicz K. - Etyka $w$ marketingu $i$ marketing wetyce biznesu - metaforyczność, konwencjonalizm $i$ zakorzenienie. Wydział Zarządzania, Uniwersytet Warszawski, School of Science and Engineering, TITech (Tokyo Institute of Technology), Warszawa, 2004, http://www.etykabiznesu. com.pl/.

[66] Kneader N., Gray R.H., Power D.M., Sinclair C.D. - Evaluating the Performance of Ethical and NonEthical Funds: a Matched Pair Analysis. Working Paper, 2001.

[67] Knox S., Gruar C. - The Application of Stakeholder Theory to Relationship Marketing Strategy Development in a Non-profit Organization [in] Journal of Business Ethics, 2007, Vol. 75, pp. 115-135.

[68] Kobylański A., Szulc R. - Development of Marketing orientation in Small and Medium - Sized Enterprises, Evidence from Eastern Europe [in] International Journal of Management and Marketing Research, Vol. 4, No. 1, 2011.

[69] Korhonen J. - Should We Measure Corporate Social Responsibility? [in] Journal of Corporate Social Responsibility and Environmental Management, 10 (1), 2003, pp. 25-39.

[70] Kotler P., Keller K..L., Brady M., Goodman M., Hansen T. - Marketing Management. Pearson, London 2009.

[71] Kotler P., Amstrong G. - Principles of Marketing, global edition. Pearson, London 2011.

[72] Kotler P., Kartajya H., Setiawan I. - Marketing 3.0: from Products to Customers to the Human Spirit. John Wiley \& Sons, Inc. Hoboken New Jersey, 2010.

[73] Kotler P., Caslione J. A. - Chaotics - The Business of Managing and Marketing in the Age of Turbulence. AMACOM American Management Association, New York, 2009. 
[74] LeBlanc D.C. - Statistics: Concepts and Applications for Science. Jones \& Barlett Publishers, 2003, pp. 245-246.

[75] Łepko Z., Sadowski R. (ed.) - A Humanist Approach to Sustainable Development. UKSW, Warszawa 2009.

[76] Lopez V.M., Garcia A., Rodriguez L. - Sustainable Development and Corporate Performance: A Study Based on the Dow Jones Sustainability Index [in] Journal of Business Ethics, Vol. 75, No. 3, 2007, pp. 285-300.

[77] Lorraine N.H., Garcia A., Rodriguez L. - An Analysis of the Stock Market Impact of Environ-mental Performance Informatio [in] Accounting Forum, 2004, Vol. 28, No 1, pp. 7-26.

[78] Luo X., Bhattacharya C.B. - Corporate Social Responsibility, Customer Satisfaction and Market Value [in]. Journal of Marketing, 70 (June), 2006, pp. 1-18.

[79] Lux J., Thorsen S.S., Meisling A. - Corporate Social Responsibility: Chapter 19, The European Initiatives. International Bar Assciation, 2005.

[80] Mackey A., Mackey T.B., Barney J.B. - Corporate Social Responisbilty and Firm Performance: Investor Preferences and Corporate Strategies [in] Academy of Management Review, Vol. 32, No. 3, 2007, pp. 817-835.

[81] Martens P., Akin, Su-Mia Maud Huynen, Raza M. - Is Globalization Healthy: A Statistical Indicator Analysis of the Impacts of Globalization on Health [in] Globalization and Health, 2010, Vol. 6, No. 16.

[82] McWillims A., Sigel D. - Corporate Social Responsibility: a Theory of the Firm Perspective [in] Academy of Management Review, Vol. 26, No. 1, 2001, pp. 117-127.

[83] Mersino A. - Emotional Intelligence for Project Managers: The People Skills You Need to Achieve Outstanding Results. Saranac Lake, NY, USA: AMACOM Books, 2007, p. 8.

[84] Minzberg H. - The Case for Corporate Social Responsibility [in] Journal of Business Strategy, No. 4, 1983, pp. 3-15.

[85] Moon J. - Government as a Driver of Corporate Social Responsbility. ICCSR Research Paper Series, No. 20, 2004.

[86] Nelling E., Webb E. - Corporate Social Responsbility and Financial Perfroance: the "Virtuous Circle" Revisited [in] Review of Quantitative Finance and Accounting, No. 32, 2009, pp. 197209.
[87] Orlitzky M., Schmidt F.L., Rynes S.L. - Corporate Social and Financial Performance: a MetaAnalysis [in] Organization Studies, Vol. 24, No. 3, 2003, pp. 403-411.

[88] Pape J., Rau H., Fahy F., Davies A. - Developing Policies and Instruments for Sustainable Household Consumption: Irish Experiences and Futures [in] Journal of Consumer Policy, 2011, No. 34, pp. 25-42.

[89] Perrini F., Pogutz S., Tencati A. - Developing Corporate Social Responsibility: A European Perspective. Edward Elgar Publishing, 2006.

[90] Polonsky M., Jevons C. - Global Branding and Strategic CSR: an Overview of Three Types of Complexity [in] International Marketing Review, Vol. 26, No. 3, 2009. pp. 327-347.

[91] Porter M.E., Kramer M.R. - Creating Shared Value. Harvard Business Review, January-February 2011.

[92] Preston L.E., O'Bannon D.P. - The Corporate Social-Financial Performance Relationship: A Typology and Analysis [in] Business \& Society, Vol. 36, No. 4, 1997, pp. 419-429.

[93] Redesigning Busines Value: A Roadmap for Sustainable Consumption, World Economic Forum Report, Geneva, January 2010.

[94] Ren L., Xie G., Krabbendam K. - Sustainable Competitive Advantage and Marketing Innovation Within Firms. A Pragmatic Approach for Chinese Firms [in] Management Research Review Vol. 33, No. 1, 2010, pp. 79-89.

[95] Oudan R. - Makromarketing and Market Orientation Effects on Economic Growth a Contceptualization Model [in] Proceedings of the Academy of Marketing Studies, Vol. 13, No. 1, Tunica, 2008.

[96] Ryan L.V., Sójka J. (ed.) - Etyka biznesu: Z klasyki współczesnej myśli amerykańskiej, Wydawnictwo W Drodze, Poznań 1997 (in Polish).

[97] SAS - SAS Institute Inc., http://support.sas.com/documentation/cdl/en/statug /59654/HTML/default/statug_intromod_a0000000 346.htm (accessed on 2009).

[98] Schlegelmilch B.B., Oberseder M. -: Half a Century of Marketing Ethics: Shifting Perspectives and Emerging Trends [in] Journal of Business Ethics No. 93, 2010, pp. 1-19.

[99] Schlegelmilch B.B., Öberseder M. - Half a Century of Marketing Ethics: Shifting Perspectives and Emerging Trends [in] Journal of Business Ethics, Vol. 93, 2010, pp. 1-19. 
[100] Schwartz J. - Reforming the Corporation from Within [in] Corporate Social Policy: Selections from Business and Society Review (eds. Heilbroner R.L. and London P.), AddisonWesleypublishing Co, London 1975, pp. 12-18.

[101] Shane P.B., Spicer B.H. - Market Response to Environmental Information Produced Outside the Firm [in] Accounting Review, No. 58, 1983, pp. 521-538.

[102] Singhapakdi A., Karande K., Rao C.P., Vitell S. J. - How Important are Ethics and Social Responsibility? A Multinational Study of Marketing Professionals [in] European Journal of Marketing, Vol. 35, No. 1/2, 2001, pp. 133-152.

[103] Sirgy M.J., Dong-Jin L. - Setting Socially Responsible Marketing Objectives - a Quality-Of-Life Approach [in] European Journal of Marketing, Vol. 30, No. 5, 1996, pp. 20-34.

[104] Smith K.G., Hitt M.A. - Great Minds in Management: The Process of Theory Development. Oxford University Press, Oxford, 2005.

[105] Social Investment Forum - Report on Socially Responsible Investing Trends in the United States [at] Social Investment Forum, Washington 2007, http://www.socialinvest.org/resources/research/

[106] Springer R., Czinkota M.R. - Marketing's Contribution to the Transformation of Central and Eastern Europe [in] Thunderbird International Business Review, Vol. 41, No. 1, pp. 29-488, January / February 1999.

[107] Strong N. - Modelling Abnormal Returns: A Review Article [in] Journal of Business, Finance and Accounting, 19(4), June 1992, pp. 533-553.
[108] Vaaland T. I. Morten H., Grønhaug K. - Corporate Social Responsibility: Investigating Theory and Research in the Marketing Context [in] European Journal of Marketing. Vol. 42, No. 9/10, 2008, pp. 927-953.

[109] Viswanathan M. - Measurement Error and Research Design. Sage Publications, 2005.

[110] von Arx U., Ziegler A. - The Effect of CSR on Stock Performance: New Evidence for the USA and Europe. Swiss Federal Institute of Technology Working Paper 08/85, 2008.

[111] Vyakarnam S. - Social Responsibility: What Leading Companies Do [in] Long Range Planning, Vol. 25, No. 5, 1992, pp. 59-67.

[112] Waddock S.A., Graves S.B. - The Corporate Social Performance-Financial Performance Link [in] Strategy Management Journal, Vol. 18, Issue 4, 1997, pp. 303-319.

[113] Williams C.A., Aguilera R.V. - Corporate Social Responsibility in a Comparative Perspective. The Oxford Handbook of Corporate Social Responsibility, Oxford University Press, 2008.

[114] Williams E. - CSR Europe's Sustainable Marketing Guide: 4Ps for 3Ps. CSR Europe, www.csreurope.org, Brussels, Belgium 2010.

[115] Zadek S., MacGillivray A. - The State of Responsible Competitiveness 2007: Making Sustainable Development Count in Global Market. Account Ability, July 2007. 